\title{
A viagem como experiência traumática na ficção Paisagem de porcelana, de Claudia Nina
}

\author{
Bruno Cardoso*
}

\begin{abstract}
Resumo
O artigo analisa a representação da experiência de deslocamento no romance Paisagem de porcelana, da escritora carioca Claudia Nina. A leitura da obra focaliza os expedientes narrativos empregados pela autora com o objetivo de figurar a viagem da protagonista-narradora à Holanda sob uma moldura traumática e dramática. Assim, o enredo se constrói sob uma perspectiva memorialista, conforme Cury (2016), comumente utilizada em narrativas de viagem. A hipótese de leitura sustenta que a narradora, enquanto rememora os acontecimentos traumáticos ocorridos em sua experiência de viagem a Amsterdã, produz um discurso de ficção que apara as arestas deixadas pela experiência traumática. Em consequência disso, a possibilidade de superar a experiência traumática de viagem se viabiliza, no romance, por intermédio da criação de uma escrita ficcional sobre ela, o que se revela como estratégia narrativa crucial para a construção do enredo.

Palavras-chave: Literatura brasileira contemporânea. Cláudia Nina. Viagem. Memória. Trauma.
\end{abstract}

* Universidade de Brasília (UnB). Mestre em Língua Portuguesa pela Universidade Federal de Santa Catarina e doutorando em Literatura e Práticas Sociais pela Universidade de Brasília (UnB). 


\section{Migrantes e deslocados: um tema na ordem do dia}

"Número de refugiados no mundo supera 60 milhões pela primeira vez". A manchete do jornal O Globo, de 20/06/2016, apresenta uma estatística que nos põe atônitos e que, por si só, se apresenta como um corolário irrefragável da célebre afirmação de Edward Said:

Mas a diferença entre os exilados de outrora e os de nosso tempo é de escala: nossa época, com a guerra moderna, o imperialismo e as ambições quase teológicas dos governos totalitários, é, com efeito, a era do refugiado, da pessoa deslocada, da imigração em massa (SAID, 2003, p. 47).

Esse volume maciço de pessoas deslocadas, em exílio, ou refugiadas, vem aumentando, nos últimos anos, sobretudo, em razão dos conflitos sírios, cujo fim parece imprevisível. Enquanto isso, não falta esperança, lágrimas, desespero, luto, dor e travessias. De travessias duas grandes narrativas fundantes da nossa literatura ocidental se fizeram: o "Êxodo" bíblico e a Odisseia, de Homero. Assim, quando a literatura investe em questões de migração, de deslocamentos, de grandes diásporas, não deixa, de alguma forma, de instaurar um diálogo com essas epopeias antigas cujo enredo abordava a experiência de viagem numa esteira coletiva, pautada, assim, na fundação de um discurso de nação.

A modernidade líquida tem nos propiciado, ainda que sob vias trágicas, a ascensão do desespero em massa de quem intenta migrar para outro território em busca de um estado de paz, onde se possa tocar a vida longe do estado de exceção que demarca os grandes conflitos civis. $\mathrm{O}$ tema se revela atual e ganha corpo cada vez mais na literatura contemporânea. Fato é que, num mundo pautado por grandes experiências de deslocamentos, quer sejam coletivos ou individuais, o tema da mobilidade, ou, mais precisamente, da viagem, ganha musculatura na produção literária contemporânea, ainda mais quando se pensa a literatura como prática social, ou, grosso modo, como um espelho refrator e problematizador das questões de seu tempo.

É certo, contudo, que experiências de viagens não se constituem como uma novidade formal ou temática na prática literária, artística e crítica. O célebre ensaio de Walter Benjamin (2000), com ênfase no estatuto da figura do narrador, bem o demonstra, deixando premente a associação entre a figura do narrador contador de histórias e a figura do viajante que volta trazendo na bagagem um punhado de experiências e 
ensinamentos para compartilhar. Lukács (2000), ao analisar a formação do gênero romance como uma epopeia da vida burguesa, o faz contrapondo-o ao gênero épico dos tempos idos, gênero associado pelo teórico alemão a uma experiência soberana de coletividade, sem a qual o herói não avança em suas peripécias, de sorte que a Odisseia, pioneira expedição fictícia, comparece como um exemplo emblemático desse postulado. Queiroz (1998), por vias parecidas, considera a literatura antiga como chave de viagem para pensar as figurações do exílio à luz da relação dos heróis antigos com o desígnio dos deuses. Em seu vasto compêndio sobre a representação das experiências de deslocamento na literatura ocidental, a pesquisadora indaga sobre a atualidade de um tema tão fertilmente explorado ao longo dos séculos, obviamente, com as devidas colorações e matizes estético-ideológicos de cada tempo. A notícia do jornal O Globo revela-nos que chegamos a tempos pautados por experiências traumáticas de migração e deslocamentos coletivos, cuja consequência capital reside em convidar a literatura a um repensar da atualidade dessa matéria narrativa.

Nesse quadro, Cury (2015) defende uma conformação de um "imaginário da mobilidade", na medida em que a contemporaneidade se perfaz sob uma dinâmica híbrida, sem lugares fixos, que diz mais de rotas do que de raízes. Esse imaginário encampa, sobretudo, as tensões sociais impetradas pelo processo de globalização, de modo que, no dizer de Cury (2015, p. 187), “o espaço da produção artística se deixa atravessar pelas mobilidades contraditórias presentes em nossa época”.

Nesse cenário, Bauman, expoente da modernidade líquida e das nefastas contradições do processo de globalização, assinala, de forma contundente: "Os refugiados, os deslocados, as pessoas em busca de asilo, os migrantes, os 'sans papiers', constituem o refugo da globalização" (BAUMAN, 2005, p. 76). Essa proliferação de refugos delegada pela era moderna confere a essas experiências de errância contemporâneas um caráter sui generis em relação às experiências de deslocamentos de outrora, pois, como salienta Michel Maffesoli (2001), tais errâncias parecem evocar a mobilidade como signo contraditório dos tempos atuais. Contradição que se revela, principalmente, nas tentativas, muitas vezes, inócuas de se erigirem barreiras ou de se materializarem fronteiras com o fito de refrear ou obstar as ondas migratórias. Muller (2011) visualiza essa contradição, sobretudo, na exacerbação de fronteiras e na reafirmação ultramaterial de geografias imaginárias. Segundo a pesquisadora,

[...] tal cenário nos faz pensar que, embora o nomadismo seja uma característica que acompanha homens e mulheres desde os primórdios, a fixação na terra através do sedentarismo acabou por reforçar, com o passar do tempo, uma identificação tão acentuada entre membros de um mesmo grupo, que a rejeição dos 'diferentes', cujo pertencimento 
poderia ser - e de fato é - colocado à prova, parece natural (MULLER, 2011, p. 15).

Essa hiperbolização das fronteiras e das geografias imaginárias pode ser lida como um efeito da formação dos estados-nação ocorrida numa era marcada, alhures, pela experiência do sedentarismo. Cacciari se alinha com essa formulação quando assevera que: "Em realidad, la historia de este siglo, marcada, em cierto sentido, ideológicamente, por uma política iluminista-romántica, es la historia del fin progressivo de todo espaço de cohabitacion". ${ }^{1}$ (CACCIARI, 1996, p. 18). Em consequência, abordar a temática da mobilidade, em um momento de hiperbolização das fronteiras materiais, propala um desiderato pela estética da contradição, do choque, dos confrontos identitários emergidos do encontro entre o estrangeiro e o hospedeiro, ainda mais quando, conforme Cacciari (1996), as figuras do hóspede, do inimigo e do estrangeiro se confundem.

A obra escolhida para análise - Paisagem de porcelana, publicada em 2014, pela Editora Roxxo, da escritora carioca, jornalista e doutora em Letras, pela Universidade de Utrecht, Claudia Nina - trata de viagem e de migração, mas de uma viagem que se torna, para a protagonista-narradora, Helena, uma experiência taciturnamente traumática. De trauma, de luto, de dor e de esperança é que se tecem os fios que tramam o enredo da obra de Claudia Nina, fios que dialogam, de alguma forma, com esse torvelinho migratório em voga atualmente. Investigar como a autora capitaliza essas tensões e constrói a representação da experiência de migração e viagem, em sua narrativa, apresenta-se como o objetivo deste artigo. A relevância da reflexão aqui empreendida se justifica pela qualidade estética do livro em análise e pela atualidade das questões nele suscitadas, bem como pela ainda inexistente fortuna crítica relativa à obra. ${ }^{2}$

\section{Entre a turistagem e a vagabundagem}

A contemporaneidade, na visão de David Harvey (2008), é demarcada por uma inconcussa compressão das relações espaço-temporais. Essa compressão, que opera por uma via de mão dupla, suscita a impressão de que, na modernidade líquida, tudo

1 Na nossa tradução: "De fato, a história deste século, marcada, em certo sentido, ideologicamente, por uma política romântico-iluminista, é a história do fim progressivo de cada espaço de convivência". $2 \mathrm{O}$ livro figurou entre os finalistas do prêmio Rio de Literatura, em 2015. 
corre mais paulatinamente, e que, num átimo de instante, as estruturas aparentemente estáveis podem se dissolver. Os estudos culturais, cujo alcance teórico visa abarcar as dinâmicas culturais da modernidade, desenvolveram um tropos, em constante remodelamento, no intuito de caracterizar cientificamente os fenômenos socioculturais em voga na modernidade, fenômenos que exploram, sobretudo, o contato entre culturas, o jogo de identificação e diferença entre o eu e o outro, entre o eu e o estrangeiro. Desse modo, Torres (2001), no artigo "Estudos americanos: raízes nacionais, rumos globais", publicado no livro Raízes e rumos: perspectivas interdisciplinares em estudos americanos, alega que

[...] os processos conflitantes e disjuntivos da contemporaneidade estão subjacentes ao significado do que vem a ser 'cidadão' no mundo de hoje, frequentemente desestabilizando ou rompendo com noções preestabelecidas de cidadania, ou de pertencimento a determinados territórios. A teoria contemporânea encontra-se tão híbrida e diaspórica quanto as populações do mundo moderno. Marcada, também, por tropos de deslocamento, ela se encontra repleta de um vocabulário espacial: local/global, centro/periferia, dentro/fora, margens, bordas, fronteiras, interstícios, não-lugar, posições, confrontações são termos recorrentes na tentativa de se dar conta da nova (des)ordem mundial. (TORRES, 2001, p. 11).

As ideias de Torres nos permitem concluir que a volatilidade desse tropos erigida pelos estudos culturais foge do paradigma filosófico essencialista, em razão, sobretudo, do dinamismo dos fenômenos culturais estudados, os quais guardam uma relação indissolúvel com as dimensões espaciais, na medida em que a crescente interdependência e intersecção de fluxos locais e globais, nacionais e internacionais levam a novas configurações, "caracterizadas por trânsitos ou bordercrossings, entre fronteiras interiores e exteriores e por espaços psicogeográficos e modelos de representação desligados de tradições e identidades estáticas ou monolíticas". (TORRES, 2001, p. 11).

Se as categorias monolíticas são dissolventes, torna-se inescapável enfatizaro caráter diaspórico desse conjunto de conceitos e taxonomias que ambicionam, principalmente, caracterizar as experiências desses sujeitos da contemporaneidade cuja experiência cultural se instaura em situação de mobilidade. ${ }^{3}$ Said (2003) ensaia um movimento

3 Nesse sentido, vale a pena ler as ressignificações pelas quais o conceito de diáspora vem passando nos estudos culturais conforme o exercício de escrutínio do conceito levado a cabo por Silviano Santiago (2016). Conferir também o texto de Maria José de Queiroz (1998) no qual se abordam as múltiplas nuances do conceito de exílio. 
nesse sentido ao distinguir exilados de emigrados, expatriados e refugiados. Bauman (1999), no livro Globalização: as consequências humanas, apresenta os conceitos de "turista" e "vagabundo" para abarcar os principais tipos de mobilidade insuflados pela dinâmica da vida global — instaurada sob a égide da contradição —, haja vista que a globalização, conforme seu modo de pensar, tanto divide como une, bem como divide enquanto une. Sendo assim, os conceitos-metáfora de turista e vagabundo são pensados pelo sociólogo como um modo de sublinhar os vencedores e as vítimas em meio ao avanço da globalização, pautado por um regime capitalista flexível e atroz, e suas nefastas consequências humanas, de forma que a oposição entre os turistas e os vagabundos se revela como a principal divisão da sociedade pós-moderna fincada em relações de mobilidade e consumo (BAUMAN, 1999).

Bauman ecoa o pensamento de David Harvey (2008), ao discorrer sobre as relações comprimidas de espaço-tempo, relações colimadas na inquieta sensação de mutação constante, na qual a habilidade de se mover comparece como um fator capital para lograr-se êxito no sistema de capitalismo flexível. Com isso, emerge, no aparato teórico de Bauman, o conceito de turista, o qual abarca aqueles que se recusam a qualquer tipo de fixação, de estabilidade definitiva, em suma, de guardarem um lugar peremptório para chamarem de seu, com efeito, movimentamse porque assim o preferem, porque assim o querem, de forma que saem e chegam a qualquer tempo e a qualquer espaço, com o fito de construírem a materialização de seus sonhos, projetos e saciarem suas necessidades de consumo e de estilo de vida mais prementes. Os vagabundos, por sua vez, "são luas escuras que refletem o brilho de sóis brilhantes; são os restos do mundo que se dedicaram aos serviços dos turistas" (BAUMAN, 1999, p. 94). Movimentam-se porque estão sendo empurrados pela necessidade de sobrevivência, e, mesmo assim, existem severas restrições nos tempos-espaços pelos quais eles perambulam. Dessa maneira, seus sonhos e fantasias resumem-se a um emprego qualquer, amiúde executam tarefas consideradas humilhantes que demandam ser empreendidas por alguém.

Esse esforço de taxonomia para os sujeitos moventes da modernidade foi trazido à reflexão por conta da especificidade da experiência de viagem protagonizada no livro Paisagem de porcelana pela narradora da história, Helena. Até que ponto uma experiência, inicialmente, de viagem prolongada de estudos, tal qual a vivida pela protagonista-narradora Helena, pode transformar-se numa experiência de exílio, na medida em que, segundo Queiroz (1998), qualquer viajante, por um tempo mais prolongado, longe da pátria, pode vir a experimentar um arrefecimento nas âncoras 
referenciais de pertencimento? Ou até que ponto tal experiência de viagem pode guardar relações, em termos psicológicos, com a experiência de um refugiado ou de um emigrado em definitivo? Assumimos, a título de hipótese de leitura, que a experiência vivenciada pela narradora Helena pende inicialmente para a condição de turista, mas logo a narradora é lançada à condição de vagabundo. Turista, porque inicialmente a narradora goza de um status acadêmico que lhe permite essa situação de deslocamento para um país estrangeiro. Vagabundo, porque, à medida que o enredo se desenvolve, a narradora-protagonista vivencia uma situação bifurcada de degradação psíquica e econômica, introduzindo-a, de forma implacável, num conjunto de vivências traumáticas que sua escrita tentará resgatar e suplantar.

O início da narrativa se reveste de uma importância nuclear para a compreensão desse percurso traçado na narrativa pela figura da escritora-viajante:

Entender o que me fez sair do Brasil não é tão difícil: aos 25 anos eu era jovem para me exigir explicações. Quis partir e pronto. Amsterdã era um roteiro lindo e sedutor; lá fui eu, mochila nas costas, sozinha, um carimbo de visto no passaporte, um curso qualquer na programação, disposição para uma vida diferente, e o resto é névoa. (NINA, 2014, p. 10).

A narrativa, dessa forma, apresenta uma protagonista que ambiciona o gozo da liberdade, da fruição estética do sentimento de mobilidade, de se estar-em-trânsito, sem um ponto estável de partida, nem tampouco um critério capital que defina o ponto de chegada. O desejo de se estar-em-trânsito leva-a para Amsterdã, bem como poderia levá-la para qualquer país: “A motivação para a viagem foi justamente testar a estranheza de outros céus" (NINA, 2014, p. 39). Tal condição de quem almeja estarem-trânsito se enfatiza na narrativa pela emblemática descrição do aeroporto no qual Helena embarca para Amsterdã, de tal sorte que essa elaboração descritiva ressoa o conceito de não lugar, arrolado por Augé (2002), de acordo com o qual

são não-lugares na medida em que sua vocação primeira não é territorial, não é a de criar identidades singulares, relações simbólicas e patrimônios comuns, mas antes de facilitar a circulação (e, dessa maneira, o consumo) em um mundo com as dimensões do planeta". (AUGÉ, 2002, p. 85).

Nos não lugares, o viajante não se sente nem "estrangeiro" nem "em sua casa", e o autóctone sente-se estranho com a perda da singularidade de seu território. A 
dinâmica desses espaços que servem apenas para nos colocar em-trânsito comparece na narrativa de Claudia Nina:

$\mathrm{O}$ aeroporto parecia uma nave espacial. Eu queria morar em uma daquelas lojas que vendem pedaços de mundo, que exibem a melhor e mais suculenta parte da Holanda. Na verdade, um aeroporto não é um país nem uma cidade: são estações de passagem — nada é de ninguém, todos cabem no mesmo espaço porque não pertencem a lugar nenhum até que reencontrem seus espaços de origem. Se eu tivesse ficado entre os que estão de passagem teria sido feliz porque tudo o que eu quis depois foi passar; queria que o tempo passasse, que eu passasse no tempo, enfim, queria que Amsterdã tivesse passado, mas foi presente perpétuo (NINA, 2014, p. 17).

É salutar sublinhar o papel de que esses não lugares se revestem, na narrativa, demarcando tanto o momento de chegada de Helena a um novo país, quanto, mais ao fim, através do cenário de uma estação de trem, o momento de fuga após um conjunto de eventos traumáticos vividos em Amsterdã. Quando de sua chegada a território holandês, Helena vai morar num quarto minúsculo de um alojamento universitário, em meio ao qual o comportamento inicial da narradora denota a pretensão de quem não conseguirá sustentar uma viagem balizada pelo ideal capitalista de viagem como um produto turístico:

Leve cheiro de mofo na recepção, depois que despachei o motorista do táxi, depositando em suas mãos metade dos florins que pretendia gastar no mês inteiro. Eu precisaria economizar muito até encontrar uma forma de ganhar dinheiro. O que eu tinha levado não ia dar nem se aquela fosse apenas uma temporada de férias. E eu não tinha ido com a intenção de férias. Fui para o que mesmo? (NINA, 2014, p. 36).

Mesmo com pouco dinheiro, Helena desfruta da experiência turística do deslocamento enquanto as condições financeiras o permitem:

A primeira semana foi um tempo isolado no calendário dos horrores. Tempos de turismo. Foi quando passeamos em um campo de flores. Uma imensidão de coloridos. Nada ali parecia real de tão bonito. Senti pelas tulipas o mesmo falso amor que senti pelos holandeses - eram bonitos demais, não poderiam ser de verdade. Era um cenário em high definition. (NINA, 2014, p. 66).

Essa leveza inicial dos primeiros dias de estada em Amsterdã vai se esfacelando gradualmente à medida que a personagem envolve-se num relacionamento traumático 
com Ernest, sobre o qual discorreremos na próxima seção. O que importa salientar, neste momento, é como a autora marca essa transição pari passu com as mudanças de estação e, consecutivamente, com um emprego salutar dos recursos lexicais na construção pictórica, pautado por um uso de cores que sublinham as sensações evocadas, quer seja pelo colorido mavioso da primavera, quer seja pela taciturna frialdade do inverno plúmbeo:

Para a maioria, a cidade é uma tranquilidade moderna. Para mim também foi durante os primeiros tempos em que vivi, livre e aventureira, na claridade do verão. Sim, vida leve e sempre a suavidade dos bondes atravessando as ruas, bicicletas retendo a pouca ou quase nenhuma poluição evidente, diamantes e museus, cerveja, arenque defumado, campos de tulipas coloridas, mercados de tamancos e de queijos suculentos, batatas fritas grossas e moinhos de vento. Casas com jardins. População bonita. Barcos cruzando canais de ponta a ponta, Veneza do Norte, quanto romantismo. Naquele cenário, porém, fiquei invisível. (NINA, 2014, p. 26).

A transição para a estação invernal se dá de forma abrupta, numa narrativa que, como veremos adiante, se constrói através de uma temporalidade descontínua, sublinhando os estilhaços que pipocam na memória traumática da narradora. No zigue-zague da narrativa, acompanhamos, de chofre, a decomposição identitária, física e econômica da personagem, enfatizada pela chegada do inverno à Holanda e pelas suas cores espraiadas através da materialidade do espaço urbano, o que resulta numa construção valorativa do espaço como ambientação, no dizer de Lins (1976), visto que o espaço, muito mais do que um elemento externo à ação, integrase, indissoluvelmente, na narrativa de Nina, às camadas psíquicas da personagem narradora, pontuando e realçando as mais variadas gamas de sentimentos vivenciadas pelo sujeito-em-trânsito-em-terra-estrangeira:

Então, o frio.

$\mathrm{O}$ inverno não era de neve forte - raramente cai nevasca para aqueles lados. Se a neve gorda fosse frequente, as paisagens se sentiriam habitadas. A neve em Amsterdã era farofa de gelo que soprava de lado, como naquela manhã na estação. Eu queria ver a neve fofa, e como criança, fazer bola, afundar meus pés. Mas quando a neve chegou, enfim, eu já não sabia quem comandava meus passos.

Me enchia de aflição ver as ruas da mesma cor e, dentro das casas, um mundo de dentro também da mesma cor, tudo mal iluminado por luzes tão frágeis. [...] E veio a chuva. Pingos finos, dos que roem tudo por dentro - o forro da alma ficou puído de tantos ratos que escaparam dos canais e foram por dentro de mim. Os holandeses já nascem impermeáveis porque viverão na chuva eterna. Uma espécie de peixe 
disfarçado de gente. Eu não: molhei-me para sempre; até hoje meus pés pingam por onde ando. Então veio Ernest. (NINA, 2014, p. 26).

A transição da personagem para a condição de vagabundagem, segundo o rótulo de Bauman, se potencializa pelo envolvimento passional com o personagem Ernest, cuja inserção na narrativa é sublinhada pela paleta de cores matizada na descrição da chegada da estação invernal. Essa ênfase em cores plúmbeas para demarcar a inserção desse personagem se justifica, sobretudo, por Ernest personificar o ápice da experiência traumática pela qual Helena, a protagonista, passará no transcurso da história, lançando-a numa situação de opressão e clausura. Com Ernest, Helena vivencia o clímax de sua ruína financeira, que se insinua desde sua chegada a Amsterdã.

A cada coisa que pagava, sentia que me empobrecia terrivelmente, mas procurava não fincar o pensamento na pobreza iminente. Ficar sem dinheiro mais rápido do que imaginava seria o pior fim de linha de todos os roteiros. Precisei cruzar um oceano para perceber no primeiro dia que não poderia ter uma vida decente com a miséria que levava na mochila, ainda que não precisasse pagar pelas aulas. (NINA, 2014, p. 43).

Dessa forma, retomando a taxonomia de Bauman, a narradora-viajante goza, inicialmente, da condição de "turista", em razão de Helena, a narradora-viajante: (i) valer-se de meios legítimos para viajar a outro continente, no caso, a narradora vai de avião para Amsterdã, conforme dito anteriormente; (ii) valer-se da oportunidade acadêmica de viajar para outro país, trata-se de um motivo que confere à narradora um determinado status para uma viagem mais prolongada; (iii) desfrutar, ainda que modestamente, da fruição estética e de consumo instilada pelo contato inicial com uma paisagem urbana que lhe é estranha e inédita. No entanto, a condição efêmera de "turista" e a transição para a condição de "vagabundo" se insinuam, na narrativa, desde a chegada de Helena a Amsterdã, tornando-se sobrevalorizadas quando a personagem se encontra com um casal que conheceu no voo de ida para Amsterdã e com quem marca um passeio turístico por algumas cidades holandesas. Esse casal figura — e por que não — hiperboliza o conceito baumaniano de turista:

Os conhecidos estavam ali porque chamei. Vieram rápido, não deviam ter nada melhor com que se ocupar naqueles dias frios, a não ser aprender a viver como ursos. Eram turistas de longa temporada, não tinham pressa em voltar para o Brasil. A viagem de Bruxelas, onde estavam, até Amsterdã era o melhor que poderia lhes acontecer, assim, de improviso. Tanto faz estarem na Holanda ou na Bélgica, eles queriam 
era tirar fotos e depois mostrar aos amigos o quanto eram felizes. A mulher parecia saber quem era e que imagem fazia no espelho. [...] O mais incrível e poético foi que, nas pequenas lojas de suvenires, onde a mulher quis comprar tudo o que as mãos conseguissem abraçar e enfiar na bolsa, senti uma súbita alegria, quase tão real quanto a tristeza. Guardei a imagem no álbum de fotos que montava na minha cabeça. Aqueles mundos pincelados eram cenários românticos, habitados por borboletas, flores e homens simples que viviam uma rotina clareada e feliz. Era uma ilha de paz isolada. As lojas aquecidas e iluminadas de Delft não faziam parte do resto. Eu poderia morar no azul e fingir que o país era de porcelana. (NINA, 2014, p. 22).

Vê-se o papel de contraponto que a inserção momentânea desses personagens assume no enredo. Enquanto Helena sentia-se empobrecendo a cada vez que comprava algo, o casal de desconhecidos, por seu turno, desfrutava da viagem como um produto capitalista, feito para o consumo imediato. Para estes, viajar era adquirir suvenires, símbolos da ostentação cumulativa das viagens, bem como gozar do poder simbólico suscitado pelas imagens fotográficas angariadas ao longo das viagens turísticas. Nisso, Nina parece trazer, com sua escrita ficcional, uma nuance a mais à conceituação baumaniana de turista: aquele que se alimenta das viagens turísticas como material simbólico para autopromoção de uma imagem positiva: “A mulher parecia saber quem era e que imagem fazia no espelho". Já, para Helena, a condição de "vagabundo" se acentua à proporção que sua estada na Holanda resulta num "somatório de perdas" (NINA, 2014, p. 75), à medida que se envolve passionalmente com Ernest e cujo ápice ocorre mais ao fim da narrativa, quando a falta de dinheiro, a fome e o frio enregelante começam a marcar no corpo a situação desesperadora e aviltante de "vagabundo":

Não tinha comido nada. E de estômago vazio e torcido era fácil ver prédios desmoronando e ruas de colchão de água ou o céu baixo desabar e quebrar em pedaços como se fosse de barro. A fraqueza me deixava mambembe, tropeçando à toa e visionária, no sentido de ter visões distorcidas; mentes cansadas demais, provavelmente. (NINA, 2014, p. 175).

Ou, ainda, nesta comovente e impressionante passagem que denuncia a precária condição de Helena bordejando a de clandestinidade em terra estrangeira:

No trem havia muita gente em pé, espremida, pois os assentos estavam lotados. O abafamento me dava agonia, apesar do frio de fora. $\mathrm{Eu}$, como de costume, acuada no fundo, disfarçando o ticket usado. Era uma rotina de miséria, o frio para quem não tem dinheiro é devastador. Se 
não estivesse tão gelado, eu iria caminhando ou de bicicleta, se ainda tivesse força. Ninguém olhava para ninguém nas ruas, claro, só quando alguém fazia alguma coisa de errado. Eu estava cometendo um delito ao não pagar a passagem. Tive sorte mais uma vez. Consegui carimbar a viagem em cima de uma antiga — eram vários carimbos em cima da mesma marca. Nenhum policial apareceu para me dar lições. (NINA, 2014, p. 132).

A narrativa de Claudia Nina vai, com o desenrolar das sequências, assinalando uma experiência de tripla resistência: (i) resistência da narradora em suplantar a experiência traumatizante da viagem a Amsterdã, lançando mão da memória como um dispositivo ficcional; (ii) resistência da narradora-viajante à condição de opressão e dominação autoritária imposta pela figura masculina do personagem Ernest; e (iii) resistência da viajante-narradora às condições subalternas de sobrevivência em terra estrangeira. Exploraremos os dois primeiros itens a seguir.

\section{Memórias enevoadas do trauma}

"O resto é névoa", sentença emblemática frisada pela narradora-viajante ainda no início da narrativa, traz a lume o caráter brumoso e espesso que intervala a zona temporal que dista o plano da enunciação, marcado tipograficamente no texto como o ano de 2012, do plano dos acontecimentos, marcado tipograficamente no texto como o ano de 1998. Esse jogo de interstício entre os dois planos tensiona a narrativa e, sobretudo, a relação entre significante e significado, uma vez que, entre os acontecimentos do ano de 1998 e o plano da enunciação, há o filtro seletivo da memória.

Esse filtro da memória, veremos, opera onipresentemente na construção do texto, em virtude, sobremaneira, de a narradora Helena resgatar, com esse dispositivo mnemônico, uma experiência traumática ocorrida durante seu deslocamento à cidade de Amsterdã. Com efeito, a narrativa engendra um jogo memorialístico-ficcional cuja ambição reside em resgatar um conjunto de experiências traumáticas vivenciadas na situação de expatriada no país holandês. Assim, atuar sobre a zona bruxuleante da memória, em meio à qual a amnésia dos fatos alimenta a dor do trauma vivido, comparece como uma estratégia discursiva por parte da narradora-protagonista em não somente enfrentar a experiência traumática vivida, bem como suplantá-la e superá-la, projetando sobre ela um dado ficcional:

Escavar a névoa. Andar nevoamente por ruas sinistras e tentar enxergar o chão, com olhos de coruja, quando a luz amarela dificulta 
o reconhecimento do que é pedra e do que é buraco. Refazer meus passos até aqui — para cada lugar, um pensamento; para cada rosto esfumaçado, um nome que não lembro bem. A mente opaca ainda não consegue ver as coisas e pessoas com exatidão. A memória me salva porque não permite que eu chegue até o osso: por isso invento coisas e finjo que não consigo lembrar de tudo. (NINA, 2014, p. 11).

O campo semântico selecionado pela autora investe sobre a erosão dos contornos sofrida pelas imagens com o passar do tempo. Para forjar um discurso, valendo-se da memória como um dispositivo, faz-se premente "escavar a névoa". Escavação que, ao invés de garantir à narradora o exato encontro do referente com o seu significante, produz ainda mais uma zona de interstício entre ambos, levando o significado à condição de deriva, à qual, ato contínuo, Helena também se entregará com o desenrolar dos acontecimentos. É sintomática, na narrativa, a forma como Claudia Nina trabalha os recursos lexicais e discursivos na construção desses efeitos desestabilizadores e deformadores da memória, os quais conferem ao plano dos acontecimentos um caráter fictício, inventado, imaginado. Nesse sentido, os acontecimentos de 1998 são afetados indissoluvelmente pelo plano da enunciação (2012), em razão do filtro mnemônico, do qual a narradora se vale a fim de suturar a narrativa com as filigranas da descontinuidade, da lacuna, da imprecisão e da opacidade. A memória assume para Helena um papel terapêutico, haja vista permitir-lhe produzir, em camadas fictícias, o relato de toda a série de vivências traumáticas ocorridas em Amsterdã: ${ }^{4}$

Preciso de um pouco de fantasia e mentira doce para amolecer o que for mais violento (do pior não se falará?) e suavizar a presença de um bicho tão pesado quanto um javali, bizarro porque me aparecia com olhos claros à noite - e só os olhos, onde estava o resto do corpo? Escurecido no meio daquele quarto onde Ernest se exilava de mim e para onde eu sempre olhava à procura do que mais temia. (NINA, 2014, p. 31).

Ou, em outro instante, no qual assinala o caráter fantasioso no trato da experiência traumática: "Vou tentar, embora sempre haja mentiras cheias de fantasia, às quais recorro desde que decidi revolver o que passou" (NINA, 2014, p. 55). Recorrer a mentiras cheias de fantasias é recorrer ao poder do discurso

4 Essa relação entre trauma e fantasia, com viés terapêutico, é discutida amplamente na psicanálise e permeia, dadas as devidas diferenças, o pensamento de Freud e Lacan a respeito da experiência traumática. Para um aprofundamento na discussão psicanalítica quanto ao assunto, sugiro a leitura da tese doutoral de Berta (2012). 
ficcional no anelo de obturar as marcas acarretadas pelo trauma, trauma que se personifica na figura de Ernest, um nativo holandês, filho de um paquistanês, pelo qual Helena se apaixona irracionalmente e cujo envolvimento a lança numa teia vertiginosa de paixão e opressão. A partir disso, Ernest passa a ser comparado, com nuances impressionistas, à figura insólita de um javali, sendo que tal envolvimento se narra "em golfadas" (NINA, 2014, p. 7), num vaivém ininterrupto em que peças do enredo são postas na materialidade do texto, a esmo, cabendo ao leitor montá-las a seu contento a fim de dar forma ao percurso palmilhado pela narradora no processo de escrita-de-si.

Entre golfadas espasmódicas e imagens insólitas, palmilha-se a macambúzia trajetória da narradora-viajante Helena. Se tal trajetória fosse sintetizada de forma linear, obteríamos, grosso modo, a seguinte configuração de ações: (i) a ida de Helena para Amsterdã; (ii) o contato de Helena com a cidade, sua amizade temporária com uma japonesa e a tentativa de traçar relações num ambiente marcado pelo estranhamento cultural; (iii) o contato com Ernest e o desenrolar de uma paixão imediata e explosiva; (iv) o desenvolvimento gradual dos traços psicóticos perturbadores de Ernest; (v) a mudança do diminuto quarto do alojamento universitário para o quarto dos fundos do restaurante da família de Ernest; (vi) a submissão a uma experiência de orgia sexual imposta por Ernest, a descoberta, por parte da família paquistanesa e a consequente expulsão da propriedade pelos pais de Ernest; (vii) o esfacelamento da relação entre Ernest e Helena; (viii) a experiência de hipotermia que quase leva Helena a perder o movimento de um dos seus dedos; (ix) o atropelamento sofrido por Helena quando numa tentativa de fuga; e, por fim, (x) a queda nos trilhos da estação de trem que, por pouco, não a levou à morte. O retorno de Helena para o Brasil fica apenas sugerido na narrativa.

Tal cadeia de acontecimentos é plasmada sob o crivo de uma temporalidade descontínua, traduzida num ritmo narrativo zigue-zagueante, constituindo-se num dos expedientes narrativos hipotecados por Claudia Nina que haurem a narrativa com as marcas discursivas da memória traumática. Quer seja na construção de uma temporalidade descontínua, quer seja na modalização verbal dos acontecimentos com usos de adjetivos e advérbios modalizadores, quer seja na caracterização informe e opaca de cenários e personagens, ou na própria reflexão metaficcional sobre os meandros e singuralidades da escrita salpicada no transcurso da narrativa, vislumbrase um numeroso repertório de estratagemas narrativo-discursivos no afã de enformar, pela escrita ficcional, as experiências traumáticas vividas muitos anos antes, de modo 
que, nessa estreita relação entre plano temático e plano formal, cinge-se uma relação não impermeável entre a opacidade da memória e a opacidade do signo, sendo ambas construídas pari passu no plano da diegese.

A imagem de uma cidade onde as quedas são metafísicas e jamais verticais sugere esse mergulho no discurso, ou, mutatis mutandis, nas potencialidades polissêmicas evocadas pelo signo:

"Em um país sem montanhas, as quedas são metafísicas. Uma pessoa pode afundar e ninguém vê o desaparecimento. Ninguém consegue despencar de colinas ou ladeiras; a queda é do chão para o chão. Desmorona-se em um destroçamento de camadas internas, silenciosamente" (NINA, 2014, p. 7).

Apelando para o dispositivo da memória, a narrativa de Claudia Nina constrói-se em camadas, desarranjadamente dispostas na narrativa, camadas que apontam para uma subjetividade soçobrada e feita em escombros quando de sua viagem. Tais escombros constituem a matéria simbólica da experiência traumática: “O mal ficou despedaçado porque rasguei o mapa da cidade-ferradura com o esquecimento - é da reconstrução que preciso". (NINA, 2014, p. 16). Em estilhaços, o que faz é apenas potencializar a culpa e alimentar o luto. Torna-se urgente recompor os estilhaços e conferir uma nova organicidade às experiências vividas e, assim, suplantar o trauma: "E agora quantos anos já se passaram? Retroceder para avançar-voltar. Refazer todos os passos desde o primeiro". (NINA, 2014, p. 16). Ou, ainda, no dizer da narradora: "Imagens voavam na minha cabeça tão soltas e eu tentava colar o que via em algum imaginário." (NINA, 2014, p. 20). A fim de plasmar uma nova organicidade ao conjunto de vivências, tornase inelutável serpentear-se por entre as fissuras deixadas pela memória traumática:

$\mathrm{O}$ passado está dividido em mil pequenas peças. A cidade-ferradura. $\mathrm{O}$ mapa-labirinto. Os anéis. Tudo parece uma absurda confusão mental depois de tantos anos. Os episódios vêm em golfadas. Entre uma respiração e outra, abrem-se as cortinas: o cenário é falso - como os detentos jogados no deserto garantem ter visto o oásis, também crio imagens que não são verdadeiras. A memória não tem detector de mentiras e a confusão é normal acontecer em casos assim. Os pés gelam. Como retornar, então? (NINA, 2014, p. 7).

Assim, a confusão de imagens bruxuleantes catalisadas pela memória traumática reveste-se de importância basilar na construção do universo diegético da obra. Há uma zona brumosa a ser transposta pela escrita ficcional: 
Revejo as estações desde o primeiro momento em que pisei na Holanda e faço o inventário do que me sobrou: dois pés e duas mãos, dois braços razoáveis (o pulso direito não suporta peso), o rosto de volta ao pescoço e já capaz de ser reconhecido em espelhos, isto, de tudo, é o mais importante. [...] Não escuto direito ainda, mas a cabeça está lúcida, apesar da zona de escuridão. (NINA, 2014, p. 31).

Se há brumas na zona da memória, aventa-se, então, que o trauma só existe como ficção alojada na memória, de maneira que, para suplantar a experiência traumática, convertida em memória ficcional, faz-se iminente forjar um discurso ficcional sobre a própria memória ficcional, o que resulta numa narrativa em camadas, não binária, feito um palimpsesto:

São muitas as perguntas, e eu ainda sem resposta. Não sei por que preciso preencher todos os quadradinhos com um 'sim' ou com um 'não', como nos questionários orais que os holandeses fazem para os estrangeiros. É penoso isso, na maioria das vezes, a memória não é binária, e o que se conhece do passado, o mais recente ou o mais remoto, é um pedaço muito estreito do que aconteceu. (NINA, 2014, p. 33).

Essa ênfase no dispositivo mnemônico numa narrativa que trata de uma experiência traumática de mobilidade, tal qual a vivida pela protagonista de Paisagem de porcelana, não ocorre de forma gratuita, se assumirmos, baseados em Cury (2016, p. 145), que "o rastreamento das memórias do narrador é recurso recorrente nos textos que centralizam a figura do imigrante, estratégia discursiva para a expressão dos impasses da memória no mundo contemporâneo". Tais impasses sugeridos por Cury apontam para um caminho de investigação pavimentado por Giddens (2002), segundo o qual a problemática da fragmentação identitária na pós-modernidade resulta numa cascata de efeitos na constituição da insegurança ontológica e, consecutivamente, na erosão da capacidade do sujeito em sustentar um discurso biográfico coerente. Helena, a narradora-viajante, tenta, inocuamente, em seu processo de escrita-de-si, conferir alguma coerência a esses estilhaços de imagens, a essas golfadas espasmódicas de lembranças que irrompem em profusão. Cabe ao leitor compor, com os estilhaços lançados na materialidade do texto, essa organicidade. Já à Helena, a tentativa de suplantar o trauma deixado pelas suas memórias, escrevendo uma ficção sobre elas e, consecutivamente, recompor, com êxito, sua segurança ontológica. A última frase do romance, "Era eu, Helena", denuncia esse intento. 


\section{Estranha solidão}

A narrativa de Helena, a protagonista, engendra-se como uma narrativa permeada pela solidão exacerbada, solidão que se avoluma à medida que a personagem se envolve com Ernest e passa a ser oprimida diariamente pela brutalidade verbal e indiferença que recebe por parte desse personagem. A indiferença de Ernest para com Helena se acentua quando seus pais paquistaneses os expulsam do quarto dos fundos do restaurante da família, por descobrirem as experiências de orgia sexual vividas pelo casal, orgias que eram exigidas por Ernest e que a narradora, no plano da enunciação, não sabe expressar ao certo como pôde ter se submetido a elas nem tampouco como pôde ter se mantido tão submissa à opressão diária imposta por Ernest. $\mathrm{O}$ fato é que o aprofundamento da solidão instila, na personagem-narradora, uma sensação nefasta de estranhamento que viceja a cada tentativa de fuga sem sucesso tramada pela personagem em errâncias despropositadas pelas vielas de Amsterdã. $\mathrm{O}$ espaço do quarto a sufoca pela indiferença com a qual Ernest lhe trata e por não reconhecer aquele espaço privado como sendo seu: "Custei a perceber que naquela noite Ernest não voltaria para o lugar que eu, por falta de opção, chamava de casa. Era melhor que fosse assim, tudo o que eu queria era que ele sumisse de vez, já que por minha conta eu não saberia como riscá-lo daquele mapa. Era eu a intrusa." (NINA, 2014, p. 124). O espaço urbano, por seu turno, a sufoca pela indiferença dos holandeses: "Em Amsterdã eu era invisível, quem sabe em outra cidade alguém me veria?” (NINA, 2014, p. 47), e pela geografia concêntrica que desnorteia a personagem nas tentativas em vão de tentar flanar em linha reta: "Eu e minha sombra andávamos concentricamente ao redor dos famosos anéis de água”. (NINA, 2014, p. 86). Com efeito, a geografia do espaço urbano enreda a narradora-viajante numa carga de vertigem, da qual resulta uma série de quedas físicas que simbolizam a sua própria experiência traumática de viagem:

[...] anda-se sem perceber que, a qualquer momento, o chão vai se abrir. É cabalístico pensar se o número de vezes que caí na Holanda correspondeu ao número de canais concêntricos de Amsterdã. Os círculos do inverno - dei voltas e voltas ao redor do mapa até ficar tonta. Quantas foram as minhas quedas? Concêntricos — Singel, Herengracht, Keizersgracht e o Prinsengracht.

Existiu um roteiro de falências.

Penso em Anne Frank naquele quartinho, crescendo e escrevendo escondida na escuridão até ser descoberta por um delator. Como nunca fui turista em Amsterdã, não me programei para passeios de rotina, nem quis descobrir onde ficava o museu dela. Não fui exilada. Apenas passei 
por lá um tempo breve — o mesmo tempo em que a cidade passou por mim. (NINA, 2014, p. 25).

Com o fito de não se perder nesse desnorteante labirinto concêntrico, a narradoraviajante se vale de um mapa, ou seja, de uma forma de discurso ou de ficção para explorar discursivamente ou ficcionalmente o espaço urbano. Essa relação contígua entre mapa e ficção é salientada por Brandão (2005) e explorada pela autora na seguinte passagem:

Peguei o mapa e tentei entender as indicações. Descobri só naquele momento que Amsterdã tem a forma de uma ferradura — presságio de boa sorte? Acreditei. Embora não conseguisse fazer uma leitura clara de onde estavam meus pés no desenho do mapa, achei que seria divertido me perder um pouco. Mas logo depois veio o medo. Não podia me perder porque não haveria ninguém para me achar. Toda vez que abria o grande mapa do guia, eu podia jurar que as letras viravam de repente formigas, saíam do papel e escalavam meus braços e ombros, cansadas de viver aprisionadas. Fiquei tonta: formigas, anéis concêntricos, tantos canais, ruas estreitas e idênticas umas às outras, tudo tão igual. Onde achar um destino? Eu precisava traçar uma linha reta, mas só conseguia andar em círculos. Precisaria completar os pontinhos e desenhar um caminho viável no emaranhado de linhas-formigas do mapa. (NINA, 2014, p. 42).

O manejo do mapa, uma forma de discurso ficcional, segundo Brandão, pela narradora-viajante, no afã de perseguir um caminho viável, num novelo desconcertante de anéis concêntricos, revela o impasse que permeia toda a narrativa de Nina: a de se traçar uma linha reta quando se lida com experiências constitutivas da memória traumática. As passagens da narradora-viajante pelo espaço urbano são trabalhadas pela memória ficcional como potencializadoras de uma experiência de esvaziamento identitário, na medida em que tais perambulações desvelam a erosão dos referenciais de pertencimento que constituem, conforme Hall (2003, 2006), os pontos de ancoragem do processo de construção identitária. Dessa forma, à medida que a narradora perambula errante por Amsterdã, a cidade cinge no seu corpo as marcas dessa perda de uma autoidentidade reconhecível. Se, para Brandão (2013) e Cacciari (2005), o tratamento crítico da noção de espaço não prescinde da noção de corpo, visto que o conceito de espaço é sempre um conceito relacional, na narrativa de Claudia Nina, essa relação se marca de forma indelével, visto que a própria experiência de deambulação pelo labirinto concêntrico do espaço urbano é demarcada gradativamente no corpo da 
personagem, cuja identidade não reconhece mais quando confrontada com um objeto especular:

Eu buscava algum antídoto contra aquela maldição, quanto mais me desesperava em agonia silenciosa mais meu rosto fugia de mim. Não pertencia à Holanda na mesma proporção que a Holanda ignorava a minha presença, não seria aquele momento que a situação iria se modificar, quando eu havia perdido o que mais me qualificava diante de mim: a cara com que vim ao mundo (NINA, 2014, p. 103).

A cidade, tanto pela sua desconcertante geometria de formas, quanto pela sua radicalidade climática, se mostra implacável com a feição corporal da narradoraviajante, que não consegue passar incólume pelos ruídos, formas e projeções sensoriais dinamitadas pelo espaço urbano desse território de solidão:

Estava exausta, cada passo contra o vento era como enfiar a cara em uma máquina de entortar rostos. Não que isso fosse de grande importância, pois o que eu veria no espelho era apenas um rosto desconhecido e entortado, o menos pior dos horrores depois do choque do primeiro estranhamento". (NINA, 2014, p. 138).

A narrativa chega ao final com a protagonista-viajante triturada em pedaços:

"Eu não sabia o que estava fazendo ali, tive motivos tão frágeis para escolher Amsterdã e não sobrara um tostão furado para pensar em maquinar um retorno ao Brasil. Além do mais, eu estava em pedaços — faltava-me um rosto, uma voz. Como voltar?" (NINA, 2014, p. 104).

A saída para essa experiência traumática é evocada na própria condição de estrangeiro por parte da narradora-viajante:

"E se eu me reconhecesse no rosto de algum estranho? Aí seria o fim de tudo ou um começo de vida mais decente, quem sabe? Se eu me reconhecesse no rosto de uma holandesa típica, veria a minha cara sem precisar de espelhos". (NINA, 2014, p. 104).

É como se, nesse trecho, Helena figurasse a experiência de ser-estrangeiro, a qual, segundo Kristeva (1994), desperta em nós, a partir do contato com a alteridade, a consciência de tudo aquilo que guardamos dentro de nós e que nos faz estrangeiros para nós mesmos. Remoer as memórias do trauma, valer-se de um dispositivo ficcional a fim de reparar as fissuras dessa experiência traumática, reconstruir a identidade soçobrada, 
valendo-se do estrangeiro como alteridade especular, eis o percurso palmilhado pela narradora-viajante sintetizado na última frase do romance: "Era eu, Helena".

\title{
Traveling as a traumatic experience in Claudia Nina's novel Paisagem de Porcelana
}

\begin{abstract}
The article analyzes the representation of the experience of displacement in the novel Paisagem de Porcelana by the Brazilian writer Claudia Nina. The reading of the literary oeuvre focuses on the narrative expedients used by the author in order to portray the protagonist-narrator's journey to the Netherlands under a traumatic and dramatic frame. Thus, the plot is constructed under a memorialistic perspective, according to Cury (2016), commonly used in travel writing. The reading assumes that the narrator, while recalling the traumatic events occurred in her traveling experience to Amsterdam, delivers a fictional speech repairing the edges left by the traumatic experience. As a result, the possibility of overcoming the traumatic traveling experience is attained in the novel through the creation of a fictional writing about it, which unfolds a crucial narrative strategy for the plot's construction.
\end{abstract}

Keywords: Contemporary Brazilian Literature. Claudia Nina. Travel.

\section{Referências}

AUGÉ, Marc. Não lugares: introdução a uma antropologia da sobremodernidade. Campinas: Papirus, 2004.

BAUMAN, Zygmunt. Globalização: as consequências humanas. Tradução de Marcus Penchel. Rio de Janeiro: Jorge Zahar, 1999.

BAUMAN, Zygmunt. Modernidade líquida. Rio de Janeiro: Zahar, 2010.

BAUMAN, Zygmunt. Vidas desperdiçadas. Tradução de Carlos Alberto Medeiros. Rio de Janeiro: Jorge Zahar, 2005.

BENJAMIN, Walter. O narrador: considerações sobre a obra de Nikolai Leskov. In: OBRAS escolhidas I: magia e técnica, arte e política. Tradução de Sérgio Paulo Rouanet. São Paulo: Brasiliense, 2000.

BERTA, Sandra Letícia. Um estudo psicanalítico sobre o trauma: de Freud a Lacan. 2012. 274 f. Tese (Doutorado em Psicologia) - Instituto de Psicologia, Universidade de São Paulo, São Paulo, 2012. 
BRANDÃO, Luís Alberto. Grafias da identidade: literatura contemporânea e imaginário nacional. Rio de Janeiro/Belo Horizonte: Lamparina Editora, 2005.

BRANDÃO, Luís Alberto. Teorias do espaço. São Paulo: Perspectiva, 2013.

CACCIARI, Massimo. La paradoja del extranjero. Tradução de Dante Bernardi. Archipielago, Barcelona, v. 26-27, p. 16-20, 1996.

CACCIARI, Massimo. Nomes de lugar: confim. Tradução de Giorgia Brazzarola. Revista de Letras, São Paulo, n. 45, p. 13-22, 2005.

CURY, Maria Zilda Ferreira. Auroras migrantes. Letras de Hoje, v. 59, n. 2, p. 185-190, abr.-jun. 2015.

CURY, Maria Zilda Ferreira. Imigração no feminino: Amrik, de Ana Miranda. In: CHIRELI, Stefania; OLIVEIRA NETO, Godofredo de. (Org.). Falando com estranhos: o estrangeiro e a literatura brasileira. Rio de Janeiro: 7 letras, 2016. p. 140-157.

GIDDENS, Antony. Modernidade e identidade. São Paulo: Zahar, 2002.

HALL, Stuart. A identidade cultural na pós-modernidade. Tradução de Tomaz Tadeu da Silva e Guacira Lopes Louro. Rio de Janeiro: DP\&A, 2006.

HALL, Stuart. Da diáspora: identidades e mediações culturais. Organizado por Liv Sovik. Tradução de Adelaine La Guarda Resende et al. Belo Horizonte: Ed. UFMG, 2003.

HARVEY, David. A condição pós-moderna. São Paulo: Loyola, 2008.

KRISTEVA, Julia. Estrangeiros para nós mesmos. Tradução de Maria Carlota Carvalho Gomes. Rio de Janeiro: Rocco, 1994.

LINS, Osman. Lima Barreto e o espaço romanesco. São Paulo: Ática, 1976.

LUKÁCS, Georg. A teoria do romance: um ensaio histórico-filosófico sobre as formas da grande épica. Tradução de José Mariani de Macedo. São Paulo: Duas Cidades; Editora 34, 2000.

MAFFESOLI, Michel. Sobre o nomadismo: vagabundagens pós-modernas. Tradução de Marcos de Castro. Rio de Janeiro: Record, 2001.

MULLER, Fernanda. A literatura em exílio: uma leitura de Lavoura arcaica, Relato de um certo oriente e Dois irmãos. 2011. 272 f. Tese (Doutorado em Literatura) - Centro de Comunicação e Expressão, Universidade Federal de Santa Catarina, Florianópolis, 2011.

NINA, Claudia. Paisagem de porcelana. Rio de Janeiro: Rocco, 2014. 
OLIVIERI-GODET, Rita. Estranhos estrangeiros: poéticas da alteridade na narrativa contemporânea brasileira. Estudos de Literatura Brasileira Contemporânea, Brasília, n. 29, p. 233-252, jan.-jun. 2017.

QUEIROZ, Maria José. Os males da ausência ou a literatura do exílio. Rio de Janeiro: Topbooks, 1998.

SAID, Edward. Reflexões sobre o exílio e outros ensaios. Tradução de Pedro Maia Soares. São Paulo: Companhia das Letras, 2003.

SANTIAGO, Silviano. Deslocamentos reais e paisagens imaginárias: cosmopolita pobre. In: CHIARELI, Stefania; OLIVEIRA NETO, Godofredo de. (Org.). Falando com estranhos: o estrangeiro e a literatura brasileira. Rio de Janeiro: 7 letras, 2016. p. 15-32.

TORRES, Sonia. Estudos americanos: raízes nacionais, rumos globais. In: TORRES, Sonia. (Org.). Raízes e rumos: perspectivas interdisciplinares em estudos americanos. Rio de Janeiro: 7 letras, 2001. p. 11-26. 